\title{
Morphological and Chemical Characteristics of a Cytophaga sp. Grown under Conditions of Magnesium Excess and Magnesium Limitation
}

\author{
By AKE BOVALLIUS \\ National Defence Research Institute, Department 4, \\ S-172 04 Sundbyberg 4, Sweden
}

(Received 30 October 1978)

Cytophaga sp. NCMB 1314 produces, especially under $\mathrm{Mg}^{2+}$-limited growth conditions, a factor that liberates a cholinesterase from plaice muscle. Just after the onset of $\mathrm{Mg}^{2+}$ limitation in a batch culture, there is a period of rapid production of the factor. Changes also occur in the morphology, ATP content and gross chemical composition of the bacteria. The protein and carbohydrate contents are raised by $60 \%$ and $100 \%$, respectively, while the RNA and ATP contents are reduced to $70 \%$ and $40 \%$ of the original values. Increased amounts of carbohydrate found outside the cells after $\mathrm{Mg}^{2+}$ limitation at least partly correlated with extracellular slime observed in electron micrographs.

\section{INTRODUCTION}

A bacterium which can liberate structurally bound cholinesterase from plaice muscle was isolated by Lundin \& Bovallius (1966). The cholinesterase-solubilizing agent, called the S-factor, could be detected in sonicated bacteria and was found to have enzyme-like characteristics (Lundin, 1968). In a simple medium, the S-factor could be detected in the culture supernatant (Bovallius, 1969). Its activity depended on the $\mathrm{Mg}^{2+}$ concentration in the medium; shortly after the onset of $\mathrm{Mg}^{2+}$ starvation during growth in a $\mathrm{Mg}^{2+}$-limited medium, a sudden increase in S-factor activity was demonstrated (Bovallius, 1978). The bacterium was classified at Torry Research Station, Aberdeen, Scotland, as a probable Cytophaga sp. or a Flavobacterium sp. and was catalogued as Cytophaga sp. NCMB 1314 (T. G. Mitchell, personal communication).

In the present work, the changes in gross chemical composition, nucleotide pool and ultrastructure of the Cytophaga sp. accompanying the change from $\mathrm{Mg}^{2+}$-excess to $\mathrm{Mg}^{2+}$ limited growth were studied in relation to the observed rise in S-factor activity.

\section{METHODS}

Cultivation. Cytophaga sp. NCMB 1314 was maintained on nutrient agar slopes. Small flasks with Tryptone $\mathrm{T}$ (Oxoid; $5 \mathrm{~g}^{-1}$ ) were inoculated and incubated for $24 \mathrm{~h}$ at $30^{\circ} \mathrm{C}$ to provide inocula for the experimental cultures. The basal medium consisted of Tryptone $\mathrm{T}\left(5 \mathrm{~g}^{-1}\right)$ and $\mathrm{KCl}\left(0 \cdot 1 \mathrm{~g}^{-1}\right)$ supplemented with $\mathrm{MgSO}_{4} \cdot 7 \mathrm{H}_{2} \mathrm{O}$ at $0.05 \mathrm{~g}^{-1}$ (normal medium) or at $0.002 \mathrm{~g} \mathrm{l}^{-1}\left(\mathrm{Mg}^{2+}\right.$-limited medium). Batch and continuous cultures were grown in 11 fermenters at $30^{\circ} \mathrm{C}$ with aeration at $20 \mathrm{l} \mathrm{h}^{-1}$. Growth was measured as increase in bacterial dry weight or as absorbance at $650 \mathrm{~nm}\left(A_{650}\right)$ as described in detail elsewhere (Bovallius, 1969).

Analyses. Intracellular protein, carbohydrate and RNA were measured using the Folin-Ciocalteu, anthrone and orcinol reagents, respectively, as described by Herbert et al. (1971). Extracellular carbohydrate and RNA were determined in the culture supernatant after dialysis against cold distilled water and concentration at low pressure at $30^{\circ} \mathrm{C}$. Bovine serum albumin, glucose and yeast RNA were used as standards. S-factor activity was determined by measuring liberated cholinesterase from plaice muscle as described by Bovallius (1969). 
Extracellular and intracellular adenine nucleotides were assayed at different times during growth of Cytophaga sp. by the firefly luciferase method (Lundin \& Thore, 1975). For extraction of intracellular nucleotides from the bacterial cells, treatment for $90 \mathrm{~s}$ with boiling Tris/EDTA was adequate. Thus a portion of the whole culture (or, for determination of extracellular nucleotides, a portion of membrane-filtered culture) was transferred to a boiling solution of Tris/EDTA. After extraction, the levels of ATP, ADP and AMP were analysed in a luminometer using pyruvate kinase and adenylate kinase for the stepwise conversion of ADP and AMP to ATP (Lundin \& Thore, 1975).

Preparation for electron microscopy. Samples from the cultures were withdrawn and centrifuged in the cold; the bacteria were washed once in cold $0.9 \%(\mathrm{w} / \mathrm{v}) \mathrm{NaCl}$. They were pre-fixed in $2 \%(\mathrm{v} / \mathrm{v})$ glutaraldehyde at pH 7 and post-fixed in $\mathrm{OsO}_{4}$ (Millonig, 1962). They were then dehydrated in ethanol followed by propylene oxide, embedded in Epon (Luft, 1961) and sectioned with an LKB Ultrotome. The sections were stained with uranyl acetate (Stempak \& Ward, 1964) for 5 min and with lead citrate (Venable \& Coggeshall, 1965) for 2 min, unless stated otherwise. The silver methenamine method for localizing polysaccharide material in ultrathin sections was performed essentially as described by Walker (1969): the sections were placed on grids and stained with silver hexamethylenetetramine solution at $60^{\circ} \mathrm{C}$ for 15 to $60 \mathrm{~min}$ and subsequently treated with $2 \%(\mathrm{w} / \mathrm{v})$ sodium thiosulphate for $5 \mathrm{~min}$. Some sections were post-stained with uranyl acetate and lead citrate as described above.

\section{RESULTS}

\section{Electron microscopic studies}

The morphological changes in Cytophaga sp. during transition from $\mathrm{Mg}^{2+}$-excess to $\mathrm{Mg}^{2+}$. limited growth conditions were studied in two batch cultures, differing only in $\mathrm{Mg}^{2+}$ concentration. At different times, as indicated by the arrows in Fig. 1, culture samples were centrifuged, fixed and examined in the electron microscope.

Bacteria in exponential growth (point $2 a$, Fig. 1) varied in length between 1.9 and $3.6 \mu \mathrm{m}$ and had a diameter of about 0.6 to $0.7 \mu \mathrm{m}$ (Fig. $2 a$ ). The outer triple-layered membrane of the wall had a regular waviness which could not be seen on the inner parts. After exponential growth had ended (point $2 b$, Fig. 1), no morphological changes were seen if $\mathrm{Mg}^{2+}$ was still available in the medium (Fig. $2 b$ ). In the stationary phase (point $2 c$, Fig. 1), the bacteria appeared similar, but none were longer than $1.5 \mu \mathrm{m}$ (Fig. $2 c$ ).

In the medium with a low concentration of $\mathrm{Mg}^{2+}$, the bacteria had the exponential phase appearance (Fig. $2 a$ ) as long as free $\mathrm{Mg}^{2+}$ was present. Some 2 to $3 \mathrm{~h}$ after all the $\mathrm{Mg}^{2+}$ had been consumed (point $3 a$, Fig. 1), the wall membrane region appeared both thicker and more wavy (Fig. $3 a$ ). The number of ribosomes was reduced. After depletion of $\mathrm{Mg}^{2+}$ for $18 \mathrm{~h}$ (point $3 b$, Fig. 1), the heterogeneity of the cells was further enhanced (Fig. $3 b$ ). Some ribosomes could still be observed. On further incubation of the bacteria in the $\mathrm{Mg}^{2+}{ }_{-}$free medium, some thread-like forms appeared (Fig. $3 c$ ). In all samples, except those from old $\mathrm{Mg}^{2+}$-depleted cultures, the bacteria seemed to divide after distinct septum formation.

Thread-like slime material extended radially from the outer surface of the bacteria (Figs 27 and 3). Silver methenamine-stained sections of Cytophaga sp. showed silver granules round the bacteria in a pattern similar to the thread-like structures (Fig. 4), suggesting that the slime excretion consisted, at least partly, of polysaccharide material. More slime seemed to be produced under $\mathrm{Mg}^{2+}$-limited conditions, i.e. more silver granules were seen between the bacteria (Fig. 4a) compared with cultures grown with excess $\mathrm{Mg}^{2+}$ (Fig. $4 b$ ) (see, also, chemical analysis). Since thin sections of silver methenamine-stained bacteria had a rather pale appearance, attempts were made to post-stain lightly silver-stained sections with uranyl acetate and lead citrate to enhance the basic bacterial structures (Fig. $4 c$ ). In such micrographs the silver grains could be seen along the thread-like slime.

\section{Gross chemical analysis}

The bacterial content of $\mathrm{Mg}^{2+}$, protein, carbohydrate and RNA was followed during growth of Cytophaga sp. in medium with a limited amount of $\mathrm{Mg}^{2+}$ (Fig. 5). The amounts of these components remained relatively constant until the medium was free of $\mathrm{Mg}^{2+}$. There 


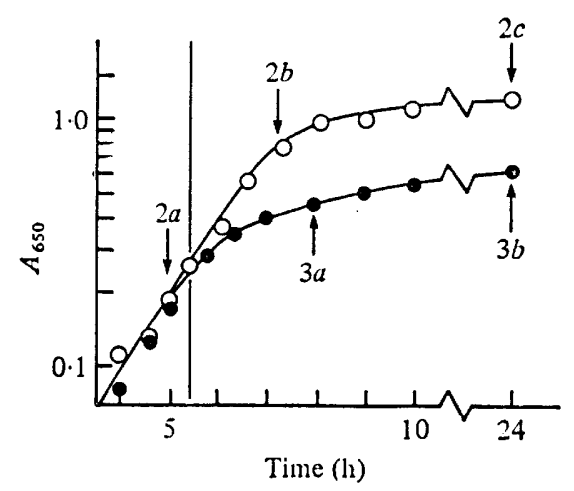

Fig. 1. Growth of Cytophaga sp. NCMB 1314 in basal medium with limited $(O)$ or excess $(O)$ $\mathrm{MgSO}_{4}$. Numbered arrows show the times at which samples were taken for electron microscopy and

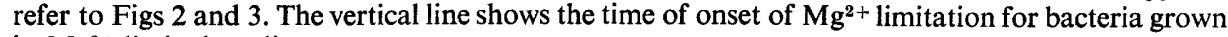
in $\mathrm{Mg}^{2+}-$ limited medium.

was then a transition phase of about 3 to $4 \mathrm{~h}$, during which the dry weight approximately doubled, and so the intracellular content of $\mathrm{Mg}^{2+}$ approximately halved, the protein content in the cells increased by $60 \%$ and the carbohydrate content by $100 \%$, while the RNA content decreased to $70 \%$ of the earlier value (all values calculated on a dry weight basis).

During the exponential growth phase little or no carbohydrate and RNA were found in the supernatant. The extracellular carbohydrate content started to increase rapidly during the transition phase. However, RNA, indicating lysis, did not appear in the culture supernatant as a direct response to $\mathrm{Mg}^{2+}-$ limited growth, and not until the end of the transition phase and in the stationary phase were readily measurable amounts detected.

Results comparable with those in batch cultures were obtained when $\mathrm{Mg}^{2+}$-limited and non- $\mathrm{Mg}^{2+}$-limited (unknown limitation) continuous cultures were run at different dilution rates. Dry weight and intracellular $\mathrm{Mg}^{2+}$, protein and carbohydrate contents of the bacteria depended on the $\mathrm{Mg}^{2+}$ content of the growth medium, while the RNA content appeared to be a function only of growth rate (Fig. 6). Extracellular carbohydrates were also found in continuous cultures, especially at low dilution rates. Greater amounts were found during $\mathrm{Mg}^{2+}$-limited growth than during growth at the same dilution rate in a non- $\mathrm{Mg}^{2+}-$ limited culture.

\section{Adenine nucleotide pool}

Adenine nucleotide contents (calculated on a dry weight basis) in an exponentially growing culture were approximately constant. When the culture became $\mathrm{Mg}^{2+}$-limited, the total adenylate pool rapidly decreased and then remained constant at the new level (Fig. 7). The decrease was almost solely due to an approximately $40 \%$ decrease in ATP content, while only a slight decrease in ADP content and a slight increase in AMP content were noted. Before $\mathrm{Mg}^{2+}$ limitation, the ATP, ADP and AMP contents were about 66, 18 and $16 \%$, respectively, of the total adenine nucleotide content. After $\mathrm{Mg}^{2+}$ limitation, the proportions were changed to 52,11 and $37 \%$. Analyses for extracellular adenine nucleotides generally showed values $<1 \%$ of those found in the whole culture. Similar results were obtained for continuous cultures run at different dilution rates.

\section{DISCUSSION}

No dramatic morphological changes could explain the sudden increase in extracellular $\mathrm{S}$-factor activity shortly after the onset of $\mathrm{Mg}^{2+}$ starvation. The electron micrographs, however, show a more complex and wavy wall membrane region in $\mathrm{Mg}^{2+}$-starved bacteria 

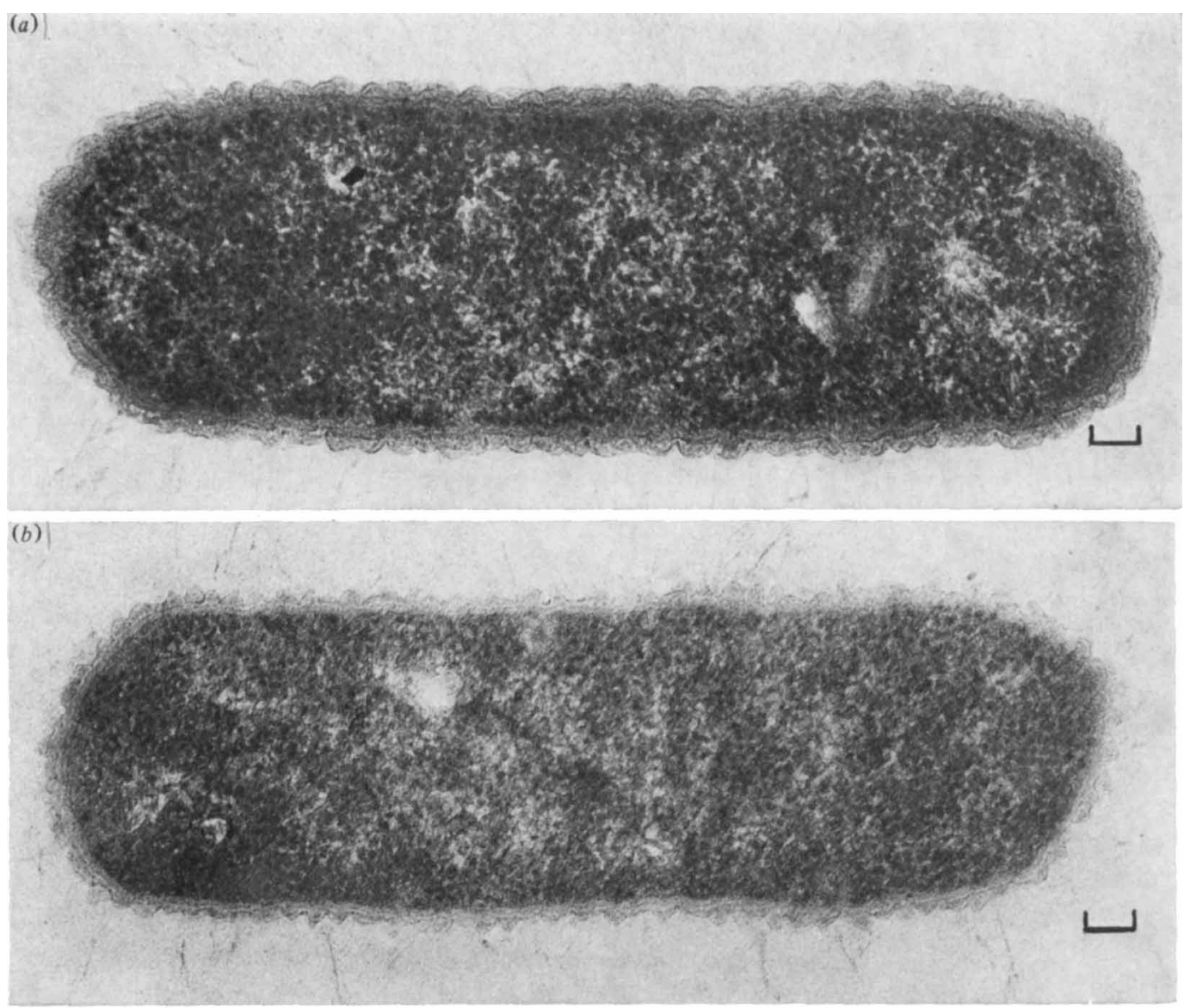

(c)

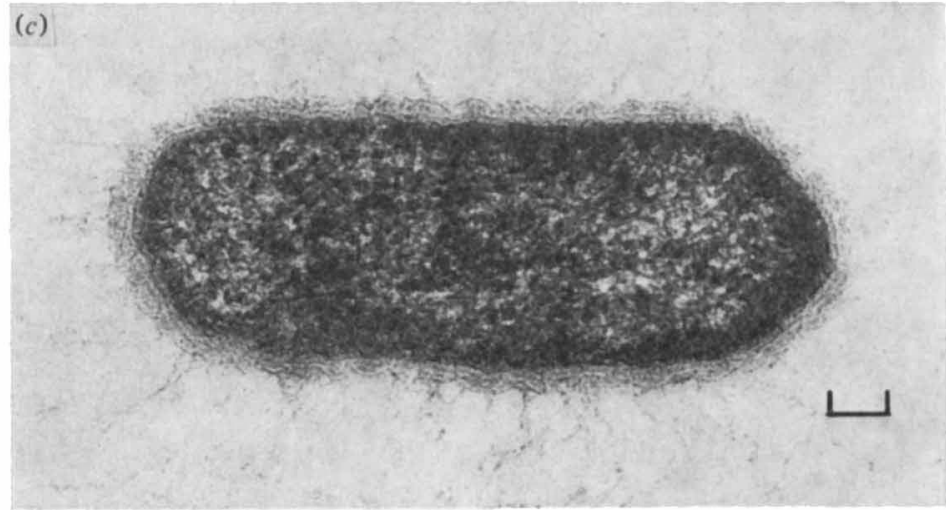

Fig. 2. Sections of Cytophaga sp. NCMB 1314, taken 5, 7 and $24 \mathrm{~h}(a, b$ and $c$, respectively) after inoculation into basal medium with excess $\mathrm{Mg}^{2+}$ (points $2 a, 2 b$ and $2 c$ in Fig. 1, respectively). Bar markers represent $0 \cdot 1 \mu \mathrm{m}$. 

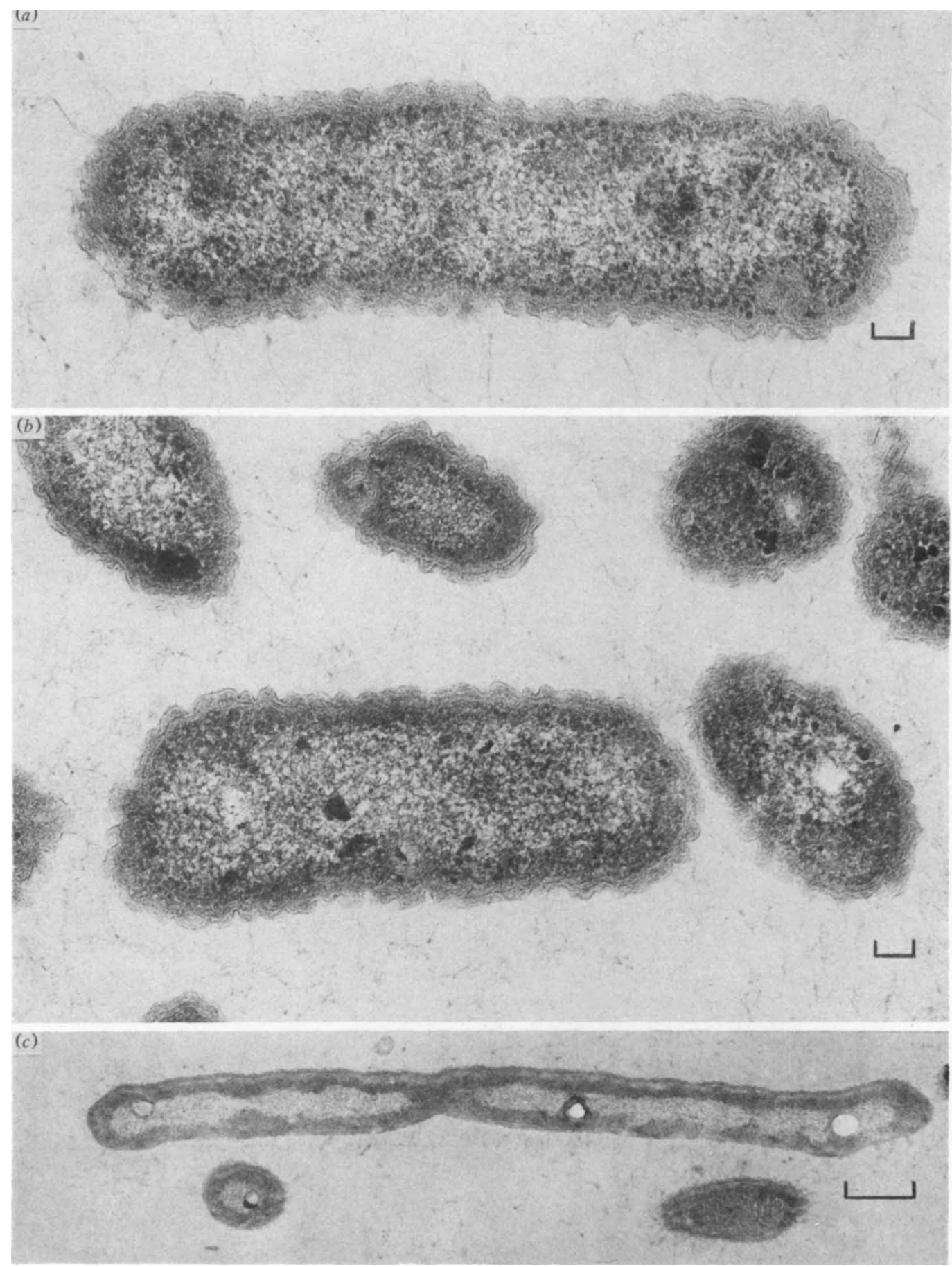

Fig. 3. $(a, b)$ Sections of Cytophaga sp. NCMB 1314 grown in basal medium with limited amounts of $\mathrm{Mg}^{2+}$, taken 2.5 and $18.5 \mathrm{~h}$ ( $a$ and $b$, respectively) after the onset of $\mathrm{Mg}^{2+}$ limitation (points $3 a$ and $3 b$ in Fig. 1, respectively). Bar markers represent $0.1 \mu \mathrm{m}$.

(c) Section of a thread-shaped Cytophaga sp. taken $48 \mathrm{~h}$ after inoculation into a $\mathrm{Mg}^{2+}$-limited medium. Bar marker represents $0.5 \mu \mathrm{m}$. 

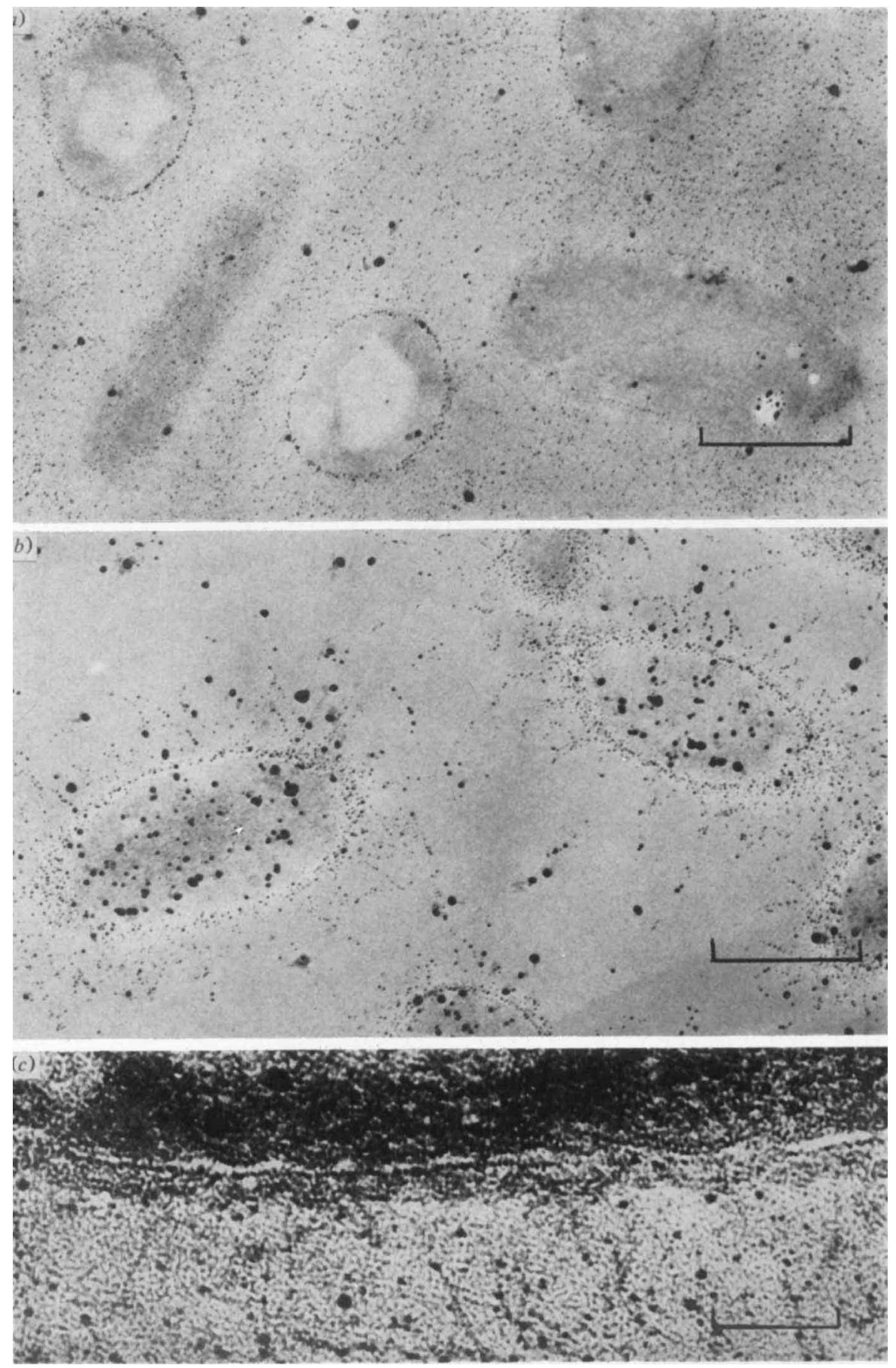

Fig. 4. $(a, b)$ Thin sections of Cytophaga sp. NCMB 1314 grown in $\mathrm{Mg}^{2+}$-limited $(a)$ or $\mathrm{Mg}^{2+}$-excess (b) medium, stained by the silver methenamine method. Apart from non-specific large silver grains, silver deposits indicating polysaccharide-containing structures can be seen on the wall, sometimes in a double layer, and in a thread-like pattern outside the organisms. Bar markers represent $0.5 \mu \mathrm{m}$.

(c) Thin section of Cytophaga sp. grown in $\mathbf{M g}^{2+-}$ limited medium, stained with silver methenamine and post-stained with uranyl acetate and lead citrate. Silver deposits can be seen on the inner dense layer of the wall and on the fibril-like threads outside the wall. Bar marker represents $0 \cdot 1 \mu \mathrm{m}$. 


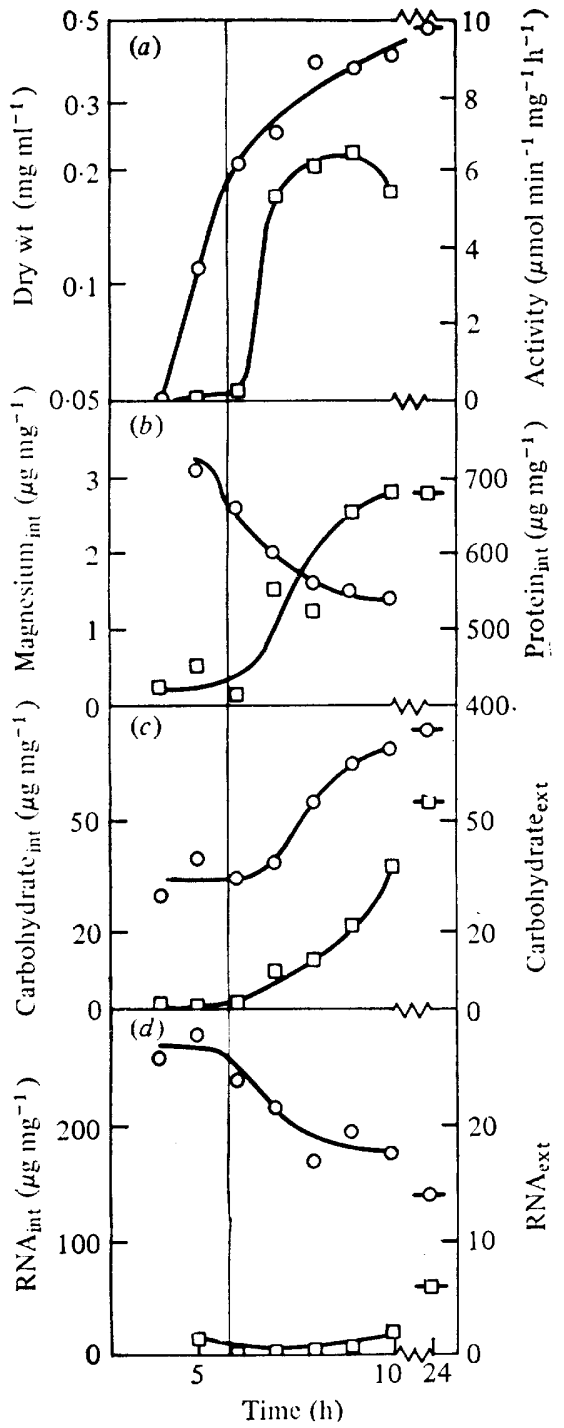

Fig. 5

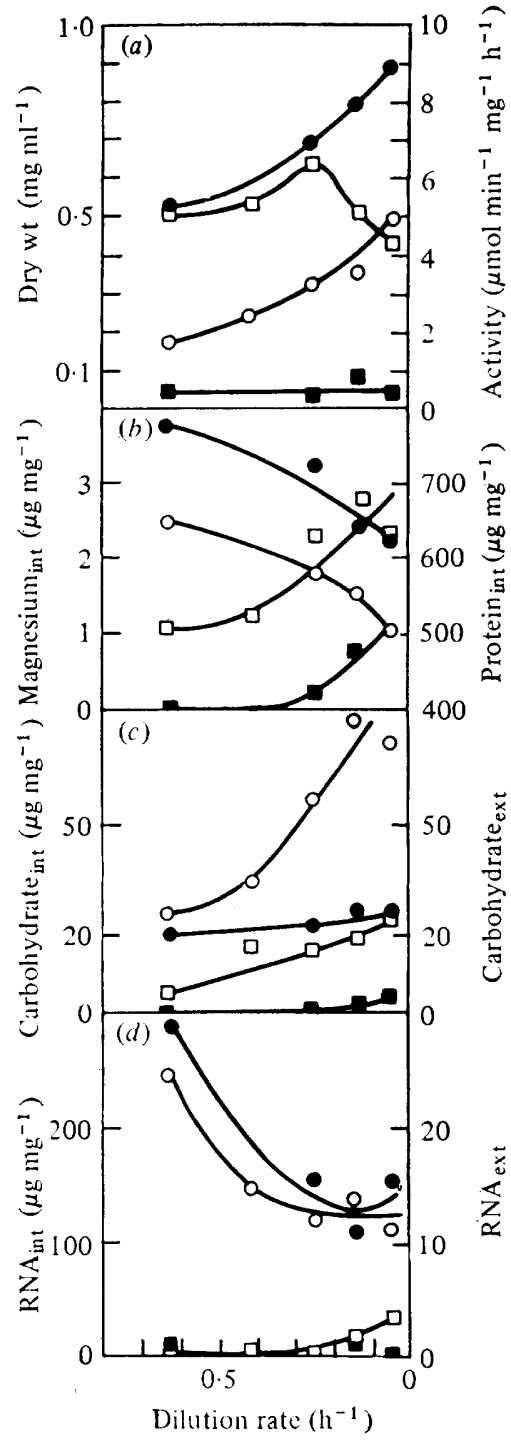

Fig. 6

Fig. 5. Changes in gross chemical content during batch cultivation of Cytophaga sp. NCMB 1314 in $\mathrm{Mg}^{2+-}$-limited medium: $(a)$ bacterial dry weight $(O)$ and extracellular S-factor activity $(\square) ;(b)$ intracellular $\mathrm{Mg}^{2+}(O)$ and protein $(\square)$ contents; $(c)$ intracellular $(O)$ and extracellular $(\square)$ carbohydrate contents; $(d)$ intracellular $(O)$ and extracellular $(\square)$ RNA contents. The vertical line shows the time of onset of $\mathrm{Mg}^{2+}$ limitation.

Fig. 6. Changes in gross chemical content during continuous cultivation of Cytophaga sp. NCMB 1314 at different dilution rates in $\mathbf{M g}^{2+}-\operatorname{limited}(O, \square)$ or non- $\mathbf{M g}^{2+-}$-limited $(\mathbf{O}, \square)$ (unknown limitation) medium: $(a)$ bacterial dry weight $(O, O)$ and $S$-factor activity $(\square, \square)$; $(b)$ intracellular $\mathrm{Mg}^{2+}(O, \odot)$ and protein $(\square, \square)$ contents; $(c)$ intracellular $(O, \odot)$ and extracellular $(\square, \square)$ carbohydrate contents; $(d)$ intracellular $(O, \bigcirc)$ and extracellular $(\square, \square)$ RNA contents. 


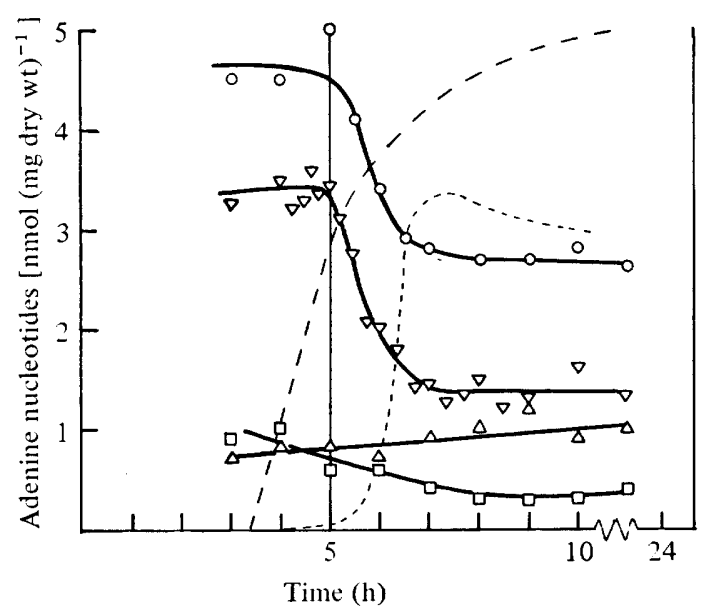

Fig. 7. Adenine nucleotide content of Cytophaga sp. NCMB 1314 during batch cultivation in $\mathrm{Mg}^{2+}$ limited medium; O, AMP + ADP + ATP; $\nabla$, ATP; $\square$, ADP; $\triangle$, AMP. The vertical line shows the time of onset of $\mathbf{M g}^{2+}$ limitation. The accompanying changes in dry weight (---) and S-factor activity (-..--) are also indicated.

than in cells grown normally, and this difference appeared within $3 \mathrm{~h}$ after the onset of starvation. The increased waviness could be a morphological artefact arising during the preparation for electron microscopy when the bacteria are exposed to chemical and physical stress. However, as the same preparation technique was used throughout, these observed differences must reflect some change in the wall structure or composition. $\mathbf{M g}^{2+}$ deficiency in Gram-negative bacteria, induced either by growth in a $\mathrm{Mg}^{2+}$-free medium or by addition of EDTA, is known to cause permeability changes (Brock, 1962) and weakened bacterial cell walls (Asbell \& Eagon, 1966). The more wavy wall during $\mathrm{Mg}^{2+}$ starvation might then result from shrinkage during the dehydration process when the wall is not stabilized to the same extent as in the presence of $\mathrm{Mg}^{2+}$ ions. In agreement with the results of other investigations (e.g. Webb, 1970), a diminished ribosome content as a result of $\mathrm{Mg}^{2+}$ starvation was clearly seen.

No difference was observed in the division patterns of Cytophaga sp. NCMB 1314 when grown under conditions of $\mathrm{Mg}^{2+}$ excess or limitation. All dividing cells formed a cross-wall prior to division. In apparent disagreement is the observation (Mitchell et al., 1969) that Cytophaga sp. NCMB 1314 forms constrictions after extended periods ( 3 to $10 \mathrm{~d}$ ) of cultivation. However, in the present study of Cytophaga sp. NCMB 1314, the cultivation time was normally limited to $24 \mathrm{~h}$. In old $\mathrm{Mg}^{2+}$-limited cultures in which thread-like forms began to appear, a division pattern characterized by a constriction of the wall without septum formation could be seen.

The silver methenamine method (Walker, 1969) was used mainly to detect whether the bacteria had a capsule or produced polysaccharide-containing slime, which is one of the properties said to characterize most species of the genus Cytophaga (Christensen, 1977), but it also gave an indication of whether different amounts of polysaccharide were produced when the bacteria were starved of $\mathrm{Mg}^{2+}$. The results suggest that more carbohydrate-containing slime is produced during $\mathrm{Mg}^{2+}$-limited growth. This observation is supported by the results from the chemical analyses of supernatants from both batch and continuous cultures which showed an increasing carbohydrate content after the bacteria became $\mathrm{Mg}^{2+}$-limited.

In batch cultures the amounts of cell-bound protein, carbohydrate, RNA and ATP (calculated on a dry weight basis) during bacterial growth changed after $\mathrm{Mg}^{2+}$ depletion in the medium. 
The changes in gross chemical composition were further analysed in $\mathrm{Mg}^{2+}$-limited and non- $\mathrm{Mg}^{2+}$-limited continuous cultures run at different dilution rates. A good correlation between results found in batch and continuous cultures was obtained when the measured parameters were compared at the same specific growth rate. The continuous culture experiments indicated that $\mathrm{Mg}^{2+}$ content, bacterial dry weight, S-factor production and extracellular carbohydrate, as well as intracellular protein and carbohydrate contents, are all dependent both on the $\mathrm{Mg}^{2+}$ content of the medium and on the growth rate, while the change in RNA content is independent of $\mathrm{Mg}^{2+}$ content and reflects only the bacterial growth rate. A similar series of experiments measuring protein, carbohydrate and RNA content in Klebsiella (Aerobacter) aerogenes and Bacillus subtilis (Tempest et al., 1965, 1967) showed the same tendency, but the percentage differences obtained were smaller than those reported here. A change to $\mathrm{Mg}^{2+}$-limited growth results in morphological and chemical changes in Cytophaga sp. reflecting at least a quantitative difference in metabolism in this system. In a batch culture all these changes are most rapid during the transient phase when the bacteria change from one metabolic state to another. It is also during this phase that the sharp increase in S-factor production is observed, although the functional relationship remains unclear.

My thanks are due to Professor Claes Weibull and Dr Arne Lundin for encouraging help and discussions, to Mrs Cecilia deLaval for skilful work with the electron microscope, to Mrs Eva Brännkärr and Miss Birgitta Jurnelius for excellent technical assistance and to Mrs Elisabeth Ericson for valuable help during preparation of this manuscript.

\section{REFERENCES}

Asbell, M. A. \& EAGon, R. G. (1966). Role of multivalent cations in the organisation, structure and assembly of the cell wall of Pseudomonas aeruginosa. Journal of Bacteriology 92, 380-387.

Bovallius, $\AA$. (1969). Production of a cholinesterasesolubilizing factor from a Cytophaga sp. by continuous cultivation. Canadian Journal of Microbiology 15, 429-433.

Bovallius, Å. (1978). Increased extracellular production of a cholinesterase-solubilizing enzyme by Cytophaga NCMB 1314 during magnesium starvation. Canadian Journal of Microbiology 24, 381-385.

Brock, T. D. (1962). Effects of magnesium ion deficiency on Escherichia coli and possible relation to the mode of action of novobiocin. Journal of Bacteriology 84, 679-682.

Christensen, P. J. (1977). The history, biology, and taxonomy of the Cytophaga group. Canadian Journal of Microbiology 23, 1599-1653.

Herbert, D., Phipps, P. J. \& Strange, R. E. (1971). Chemical analysis of microbial cells. Methods in Microbiology 5 B, 209-344.

LUFT, J. H. (1961). Improvements in epoxy resin embedding methods. Journal of Biophysical and Biochemical Cytology 9, 409-414.

Lundin, A. \& Thore, A. (1975). Comparison of methods for extraction of bacterial adenine nucleotide determined by firefly assay. Applied Microbiology 30, 713-721.

LunDin, S. J. (1968). A bacterial factor capable of solubilizing cholinesterase from plaice body muscle. Acta chemica scandinavica 22, 25192528.

Lundin, S. J. \& Bovallius, A. (1966). The solu- bilization of cholinesterase from plaice muscle by bacteria. Acta chemica scandinavica 20, 395402.

MilloniG, G. (1962). Further observations on a phosphate buffer for osmium solutions in fixation. In Proceedings of the 5th International Congress of Electron Microscopy, vol. 2, pp. 8-12. Edited by S. S. Breese, Jr. New York.

Mitchell, T. G., Hendrie, M. S. \& Shewan, J. M. (1969). The taxonomy, differentiation and identification of Cytophaga species. Journal of Applied Bacteriology 32, 40-50.

StEMPAK, J. \& WARD, R. T. (1964). An improved staining method for electron microscopy. Journal of Cell Biology 22, 697-701.

Tempest, P. W., Dicks, J. W. \& Meers, J. L. (1967). Magnesium-limited growth of Bacillus subtilis in pure and mixed cultures in a chemostat. Journal of General Microbiology 49, 139-147.

Tempest, P. W., Hunter, J. R. \& Sykes, J. (1965). Magnesium-limited growth of Aerobacter aerogenes in a chemostat. Journal of General Microbiology 39, 355-356.

Venable, J. H. \& Coggeshall, R. (1965). A simplified lead citrate stain for use in electron microscopy. Journal of Cell Biology 25, 407-408.

WALKER, P. D. (1969). The location of chemical components on ultrathin sections of Bacillus cereus embedded in glycol methacrylate. Journal of Applied Bacteriology 32, 463-467.

WEBB, M. (1970). Effects of magnesium deficiency on ribosomal structure and function in certain grampositive and gramnegative bacteria. Biochimica et biophysica acta 222, 416-427. 